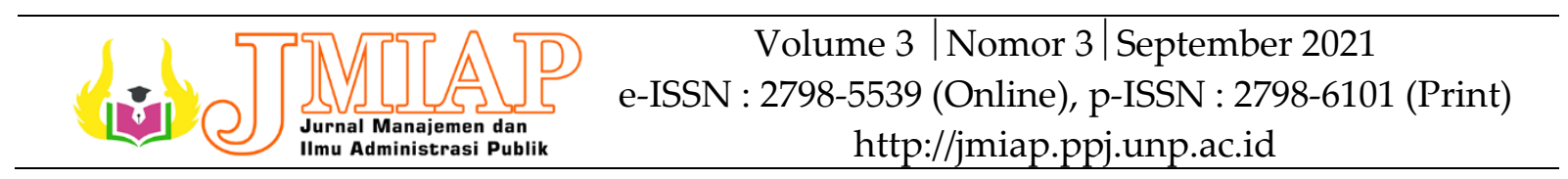

\title{
KINERJA DISKOMINFOTIKSAN KOTA PEKANBARU DALAM MENYAMPAIKAN INFORMASI TERKAIT BANTUAN SOSIAL COVID-19
}

\author{
Harapan Tua Ricky Freddy $S^{1(a)}$, Novrida Wulandari ${ }^{2(b)}$ \\ ${ }^{1,2}$ Jurusan Ilmu Administrasi Publik, Universitas Riau \\ ${ }^{a)}$ harapan.tua@lecturer.unri.ac.id, ${ }^{b}$ nvrdulan5@gmail.com
}

\begin{tabular}{l}
\multicolumn{1}{c}{\begin{tabular}{c}
\multicolumn{1}{c}{ INFORMASI } \\
ARTIKEL
\end{tabular}} \\
\hline Article History: \\
Dikirim: \\
23-07-2021 \\
Selesai Revisi: \\
16-09-2021 \\
Diterbitkan Online: \\
30-09-2021 \\
\hline
\end{tabular}

Kata Kunci:

Kinerja Organisasi, Informasi Publik, Covid-19

Ekonomi menjadi salah satu hal yang berdampak akibat pandemi Covid-19. Hal ini menyebabkan tidak sedikit masyarakat mengalami pemutusan hubungan kerja akibat dampak dari pandemi covid-19 ini. Pemerintah memberikan solusi atas masalah ini dengan cara menunjang dan membantu masyarakat yang terkena dampak untuk dapat bangun kembali. Maka dari itu, pemerintah memberikan berbagai jenis bantuan yang dihadirkan pada masa pandemi ini. Dinas Komunikasi, Informatika, Statistik, dan Persandian Kota Pekanbaru berperan dalam menyampaikan informasi terkait pemerintah kota termasuk menyebarkan informasi terkait bantuan sosial covid-19 kepada masyarakat. Informasi terkait bantuan sosial di masa pandemi ini menjadi hal yang sangat dibutuhkan bagi masyarakat terdampak. Oleh karena itu, penelitian ini bertujuan untuk mengetahui bagaimana kinerja Dinas Komunikasi, Informatika, Statistik, dan Persandian Kota Pekanbaru dalam menyampaikan informasi terkait bantuan sosial covid-19 serta apa saja yang menjadi faktor pendukung kinerja Dinas Komunikasi, Informatika, Statistik, dan Persandian Kota Pekanbaru dalam menyampaikan informasi. Konsep teori yang digunakan dalam penelitian ini adalah indikator pengukuran kinerja oleh Agus Dwiyanto (2006). Metode penelitian yang digunakan adalah metode penelitian kualitatif dengan pendekatan deskriptif melalui kegiatan wawancara, observasi, dan dokumentasi. Hasil dari penelitian ini yaitu kinerja Dinas Komunikasi, Informatika, Statistik, dan Persandian Kota Pekanbaru sudah bagus dan terampil namun perlu meningkatkan koordinasi dengan tiap OPD agar penyampaian informasi terkait bantuan sosial covid-19 menjadi lebih jelas dan faktor yang mempengaruhi kinerja dinas adalah kemampuan pegawai, motivasi kerja, lingkungan kerja, jaringan, dan koordinasi.

Keywords:

Organizational

Performance, Public

Information, Covid-19

Corresponding Author: nvrdulan5@gmail.com

DOI:

\section{ABSTRACT}

The economy is one of the things that have an impact due to Covid-19 pandemic. This has caused not a few people to experience layoffs due to the impact of the Covid-19 pandemic. The solution to this problem by supporting and assisting the affected communities to rebuild. Therefore, the government provides various types of assistance that are presented during this pandemic. The Pekanbaru City Communication, Informatics, Statistics, and Encryption Service has a role in conveying information related to city government, including disseminating information regarding Covid-19 social assistance to public. Information related to social assistance during this pandemic is very much needed for affected communities. Therefore, this study aims to find out how performance of the Pekanbaru City Communication, Informatics, Statistics, and Encoding Office in conveying information related to Covid-19 social assistance and what factors are supporting the performance of the Pekanbaru City Communication, Information, Statistics, and Encryption Service. in conveying information. The theoretical concept used in this research is the performance measurement indicator by Agus Dwiyanto (2006). The research method used is a qualitative research method with a descriptive approach through interviews, observation, and documentation. The results of this study are that the performance of the Pekanbaru City Communication, Informatics, Statistics, and Encoding Office is good and skilled but needs to improve coordination with each OPD so that the delivery of information related to COVID-19 social assistance becomes clearer and the factors that affect the performance of the office are the ability of employees, work motivation, work environment, networking, and coordination.

https://doi.org/10.24036/jmiap.v3i3.280 


\section{PENDAHULUAN}

Saat ini dunia sedang dilanda virus berbahaya. Tepat pada 31 Desember 2019, kasus pneumonia yang tidak diketahui etiologinya di Kota Wuhan, Provinsi Hubei, Cina dilaporkan oleh Who China Country Office. Pada 7 Januari 2020, Cina mengidentifikasi pneumonia yang tidak diketahui penyebabnya dari mana tersebut sebagai jenis baru dari coronavirus (coronavirus disease) atau yang sekarang kita kenal dengan sebutan COVID-19. Di Indonesia, kasus COVID-19 pertama kali dilaporkan pada tanggal 2 Maret 2020 sejumlah dua kasus.

Keberadaan virus ini menimbulkan dampak di berbagai bidang. Virus yang dapat menyerang manusia ini tentu saja memiliki dampak yang ditimbulkan berkaitan dengan manusia. Salah satu dampak yang ditimbulkan oleh pandemi ini adalah dampak ekonomi. Untuk dapat mencegah dan memutus mata rantai penularan virus ini, pemerintah mengambil kebijakan untuk melaksanakan pekerjaan dari rumah atau istilah tersebut kita kenal dengan work from home. Selain itu, di beberapa perusahaan yang juga terkena dampak wabah ini banyak melakukan Pemutusan Hubungan Kerja atau PHK terhadap karyawannya. Untuk itu, pemerintah Indonesia sudah mempersiapkan dana hingga ratusan triliun guna membantu masyarakat yang terkena dampak COVID-19, terutama masyarakat dengan kondisi ekonomi menengah ke bawah. Kementerian Keuangan menyatakan stimulus ekonomi untuk menangani dampak penyebaran COVID-19 di Indonesia melalui alokasi APBN sebesar Rp 405,1 triliun. Pada anggaran tersebut, sebesar $\mathrm{Rp} 10$ triliun merupakan alokasi untuk Jaring Pengaman Sosial (JPS). Menteri Keuangan menyatakan bahwa sektor rumah tangga, pekerja informal, korporasi, dan UMKM merupakan empat sektor yang paling terpukul akibat pandemi.

Mengenai program JPS atau disebut juga bantuan sosial untuk penanganan COVID-19 tidak berfokus pada satu program saja. Program mengenai bantuan sosial khususnya untuk yang terdampak COVID-19 ini diperkenalkan pemerintah pusat memiliki beberapa program bantuan sosial, yaitu Bantuan Sosial Tunai, Bantuan Langsung Tunai Dana Desa, Kartu Sembako, Subsidi Listrik, Kartu Pra-Kerja, dan Program Keluarga Harapan (PKH). Dari bantuan tersebut, bantuan yang berasal dari provinsi yaitu Program Keluarga Harapan
(PKH), Bantuan Sosial Pangan, dan Bantuan Sosial Tunai.

Mengenai informasi terhadap program tersebut tentu saja besar kaitannya dengan Pemerintah sebagai aktor yang berperan terhadap pelaksana program tersebut. Hal ini berkaitan dengan bagian yang menginformasikan hal tersebut kepada masyarakat yaitu bagian hubungan masyarakat.

Berdasarkan Peraturan Walikota Pekanbaru Nomor 13 Tahun 2018 tentang Kedudukan, Susunan Organisasi, Tugas dan Fungsi Serta Tata Kerja Dinas Komunikasi, Informatika, Statistik dan Persandian Kota Pekanbaru yaitu melakukan beberapa urusan rumah tangga daerah yang meliputi hubungan pemberdayaan potensi informasi, penyampaian informasi baik langsung maupun melalui media, pengembangan aplikasi TIK, statistik dan persandian.

Berdasarkan Peraturan Walikota Pekanbaru Nomor 19 Tahun 2018 tentang Pedoman Pengelolaan Pelayanan Informasi dan Dokumentasi di Lingkungan Pemerintah Kota Pekanbaru, Dinas Komunikasi, Informatika, Statistik, dan Persandian Kota Pekanbaru berperan sebagai Pejabat Pengelola Informasi dan Dokumentasi Utama di Kota Pekanbaru.

Dinas Komunikasi, Informatika, Statistik, dan Persandian Kota Pekanbaru juga berperan sebagai mediator penyampaian informasi untuk membantu instansi atau OPD lain dalam memenuhi kebutuhan informasi publik. Dinas Komunikasi, Informatika, Statistik, dan Persandian Kota Pekanbaru terutama Bidang Pengelolaan dan Layanan Informasi dan Komunikasi Publik memiliki beberapa fungsi, yaitu sebagai penyedia informasi yang berkaitan seputar instansi pemerintahan dan kebijakan walikota serta mengolah dan menginput informasi atau berita tersebut melalui media agar dapat dipublikasikan.

Permasalahan awal yang penulis temukan terdapat kritik mengenai kinerja Dinas Komunikasi, Informasi, Statistik, dan Persandian Kota Pekanbaru yang dinilai tidak dapat memberikan informasi yang jelas mengenai bantuan sosial bagi masyarakat terdampak COVID-19 serta inkonsistensi antara peraturan dan tindakan. Berdasarkan Peraturan Walikota Nomor 19 Tahun 2018 tentang Pedoman Pengelolaan Pelayanan Informasi dan Dokumentasi di Lingkungan Pemerintah Kota Pekanbaru informasi terkait program dan/ atau kegiatan yang sedang 
dijalankan dalam lingkup OPD merupakan informasi yang wajib disediakan dan diumumkan kepada masyarakat. Bantuan sosial di masa pandemi merupakan suatu program pemerintah guna menunjang dan membantu masyarakat terdampak pandemi. Oleh karena itu, informasi ini mengenai bantuan sosial ini wajib disediakan dan diumumkan secara jelas kepada masyarakat. Namun, fenomena yang terjadi, sebagian masyarakat merasa informasi yang didapatkan masih kurang jelas terkait bantuan sosial. Hal ini diperkuat oleh media mengenai kinerja Dinas Komunikasi, Informatika, Statistik, dan Persandian Kota Pekanbaru sebagai Pengelola Pelayanan Informasi dan Dokumentasi Pemerintah Daerah Kota Pekanbaru.

\section{METODE PENELITIAN}

Metode penelitian pada penelitian ini merupakan kualitatif dengan menggunakan teknik purposive sampling. Adapun lokasi penelitian berada di Dinas Komunikasi Informatika Statistik dan Persandian Kota Pekanbaru. Teknik pengumpulan data melalui wawancara dan observasi. Untuk cara pengujian keabsahan datanya dengan analisis triangulasi sumber yaitu: reduksi data, penyajian data serta penarikan kesimpulan.

\section{HASIL DAN PEMBAHASAN}

Berdasarkan temuan hasil penelitian mengenai kinerja Diskominfotiksan dalam menyampaikan informasi terkait bantuan sosial covid-19, makan pada bagian ini dijelaskan 2 hal sesuai dengan rumusan masalah yaitu:

\section{Kinerja Diskominfotiksan dalam Menyampaikan Informasi Terkait Bantuan Sosial Covid-19}

Untuk mengetahui Kinerja Diskominfotiksan dalam Meyampaikan Informasi Terkait Bantuan Sosial Covid-19, maka peneliti menggunakan lima indikator kinerja menurut Agus Dwiyanto (2006: 50):

\section{Produktivitas}

a) Kompetensi Sumber Daya Manusia Berdasarkan data pada Rencana Strategi Dinas Komunikasi, Informatika, Statistik, dan Persandian Kota Pekanbaru tahun 2017-2022, latar belakang pendidikan pegawai pada Dinas Komunikasi, Informatika, Statistik, dan Persandian Kota Pekanbaru terutama pada
Bidang Pengelolaan Informasi dan Komunikasi Publik memiliki latar belakang pendidikan yang sudah berkompeten. Hal ini dapat dilihat pada tabel berikut:

Tabel 1. Latar Belakang Pendidikan Pegawai Tahun 2020

\begin{tabular}{lcccc}
\hline \multirow{2}{*}{\multicolumn{1}{c}{ Uraian }} & \multicolumn{4}{c}{ Pendidikan } \\
\cline { 2 - 5 } & S2 & S1 & D3 & SMU \\
\hline Kepala Dinas & 1 & - & - & - \\
Sekretariat & 2 & 2 & 1 & 5 \\
Bidang Statistik & - & 3 & - & 2 \\
$\begin{array}{l}\text { Bidang } \\
\text { Persandian }\end{array}$ & - & 2 & 1 & 2 \\
$\begin{array}{l}\text { Bidang Layanan } \\
\text { Infrastruktur }\end{array}$ & - & 4 & 1 & 2 \\
$\begin{array}{l}\text { Bidang } \\
\text { Pengelolaan }\end{array}$ & & & & \\
$\begin{array}{l}\text { Informasi dan } \\
\text { Komunikasi } \\
\text { Publik }\end{array}$ & 1 & 3 & - & 2 \\
\hline
\end{tabular}

(Sumber: Rencana Strategi Dinas Komunikasi Informatika Statistik dan Persandian Kota Pekanbaru, 2017-2022)

Berdasarkan tabel di atas dapat dilihat bahwa latar belakang pendidikan pegawai Diskominfotiksan dapat dikatakan cukup bagus dan berdasarkan wawancara bersama Kepala Bidang Pengelolaan Informasi dan Komunikasi Publik menjelaskan bahwa kompetensi pegawai sudah bagus dan sudah sesuai kebutuhan organisasi serta keterampilzn pegawai juga sudah baik sehingga dalam pelaksanaan tugas sudah tidak dikhawatirkan lagi.

\section{b) Sarana dan Prasarana}

Berdasarkan data pada Rencana Strategi Dinas Komunikasi, Informatika, Statistik, dan Persandian Kota Pekanbaru tahun 2017-2022, sarana dan prasarana di kantor Dinas Komunikasi, Informatika, Statistik, dan Persandian Kota Pekanbaru secara umum dalam kondisi baik. Namun, tidak menutup kemungkinan jika ada beberapa sarana berada dalam kondisi yang tidak baik seperti mesin fotocopy, pesawat telephone, dan faximile yang mana sarana tersebut sangat dibutuhkan untuk keperluan dinas dalam memberikan pelayanan kepada publik. 
c) Program Peningkatan Kualitas

Menurut Laporan Kinerja Instansi Pemerintah Dinas Komunikasi, Informatika, Statistik, dan Persandian Kota Pekanbaru, terdapat beberapa program yang dapat meningkatkan kualitas baik dalam hal pelayanan maupun berkaitan dengan tenaga kerjanya. Dalam hal ini, Diskominfotiksan memiliki program yang berkaitan dengan penelitian ini yaitu program kerjasama Informasi dan Media Massa. Program ini memiliki beberapa kegiatan di dalamnya yaitu peneyebarluasan informasi penyelenggaraan pemerintah daerah, penyebarluasan informasi yang bersifat penyuluhan bagi masyarakat, pengelolaan website www.pekanbaru.go.id, pengelolaan majalah bertuah, pengelolaan PPID, pengelolaan opini dan aspirasi publik serta pembinaan masyarakat bidang komunikasi dan informasi.

\section{d) Sosialisasi}

Berdasarkan wawancara bersama Kepala Bidang Pengelolaan Informasi dan Komunikasi Publik dapat disimpulkan bahwa sosialisasi baik dengan masyarakat maupun antar OPD sudah dilakukan dengan baik. Namun tidak semua dapat menyerap informasi dengan baik, seperti halnya dengan masyarakat. Tidak semua masyarakat dapat menyerap informasi dengan baik sehingga tidak jarang terdapat salah informasi yang ditangkap. Keterkaitan antara sosialisasi dengan penelitian ini yaitu apabila sosialisasi berjalan dengan baik maka penyampaian informasi terkait bantuan sosial covid-19 kepada masyarakat dapat tersampaikan dengan baik.

\section{Kualitas Layanan}

a) Ketepatan Waktu

Ketepatan waktu dalam memberikan pelayanan sudah baik dan tanggap dalam memberikan pelayanan yang dilakukan oleh Diskominfotiksan terutama di Bidang Pengelolaan Informasi dan Komunikasi Publik. Kemudian, ketepatan waktu dalam menginformasikan mengenai bantuan sosial covid-19 tergantung kepada dinas yang memberikan bantuan. Apabila dinas tersebut menyampaikan informasi tersebut kepada Diskominfotiksan maka disaat itulah Diskominfotiksan dapat menginformasikannya kepada masyarakat melalui website resmi pemerintah kota. b) Sikap Petugas

Berdasarkan wawancara bersama masyarakat yang memiliki kepentingan di Diskominfotiksan disimpulkan bahwa sikap petugas atau pegawai di Diskominfotiksan sudah ramah dan sopan dalam melayani sehingga masyarakat yang memiliki kepentingan merasa nyaman dengan sikap petugas.

\section{c) Kenyamanan Tempat}

Berdasarkan pengamatan peneliti selama melakukan penelitian, kondisi sarana dan prasarana di tempat pelayanan sudah baik dan membuat nyaman. Di ruang tunggu juga tersedia pendingin ruangan dan tempat duduk sehinngga masyarakat merasa nyaman dan tidak merasa bosan jika harus menunggu hingga pelayanan selesai. Hal tersebut memperlihatkan bahwa dalam memberikan kenyamanan kepada masyarakat yang memiliki kepentingan sudah maksimal.

\section{Responsivitas}

Berdasarkan Laporan Kinerja Instansi Pemerintah Dinas Komunikasi, Informatika, Statistik, dan Persandian Kota Pekanbaru Tahun 2020. Diskominfotiksan memiliki program yang dibutuhkan oleh masyarakat, program-program tersebut yaitu Kartu Smart Madani dan LAPOR-SP4N. Kartu Smart Madani merupakan sebuah program yang dihadirkan untuk mendukung terciptanya Pekanbaru sebagai kota "Smart City" yang madani, program ini bekerja sama dengan Pemerintah Kota Pekanbaru. Kartu ini ditujukan bagi warga Kota Pekanbaru dengan berbagai fungsi yang tersedia mulai dari tabungan, tapcash, $\boldsymbol{e}$-wallet serta kartu identitas. Sementara itu, website Pemerintah Kota Pekanbaru selain digunakan untuk dapat mengakses berita mengenai kegiatan-kegiatan pemerintah kota juga dapat mengakses informasi-informasi penting. Fitur-fitur yang disediakan tersebut yaitu fitur profil kota, layanan publik, layanan perizinan dan bisnis, layanan kepegawaian, produk ukum, bank data, data statistik sektoral, info hotel pekanbaru, info restoran dan pariwisata Pekanbaru, info pusat perbelanjaan, info pasar, info pendidikan, info kerja dan pelatihan, info fasilitas kesehatan, prestasi, dan e-magazine bertuah. Namun, sebagian masyarakat tidak mengetahui ada fitur yang seperti itu di website pemerintah kota. Hal ini dikarenakan kurangnya sosialisasi ataupun 
tersebarnya informasi terkait hal ini. Kemudian, masyarakat tersebut juga mengatakan bahwa mengenai informasi terkait bantuan sosial covid-19 mereka dapatkan dari kerabat dan dari kelurahan. Sehingga hal ini dapat disimpulkan bahwa Diskominfotiksan perlu melakukan sosialisasi ataupun memberitakan kepada masyarakat terkait pelayanan mengenai akses informasi di website resmi kota.

\section{Responsibilitas}

Dalam menyebarkan informasi kepada publik tersebut memiliki prosedur, dimulai dari ditulis oleh jurnalis tiap OPD kemudian tulisan tersebut dikirim ke Diskominfotiksan. Kemudian Diskominfotiksan akan meneruskan ke ruang publik (Whatsapp Group) setelah itu masuk ke dalam dapur redaksi kemudian dipublikasikan melalui website resmi pemerintah kota.

Berdasarkan pernyataan Kepala Bidang Pengelolaan dan Layanan Informasi dan Komunikasi Publik di atas bahwa sebelum informasi diterbitkan perlu dilakukannya saringan terhadap informasi tersebut. Jika terdapat informasi yang salah namun sudah terlanjur disebarkan maka Diskominfo akan menyebarkan link ulang. Jika ada informasi resmi maka seleksinya panjang, Diskominfotiksan tidak akan menyebarkan informasi sebelum ada surat resmi terlebih dahulu, hal ini dianggap berbahaya apabila informasi langsung disebarkan begitu saja. Diskominfotiksan akan menyebarkan informasi apabila hal yang akan diinformasikan tersebut telah terlaksana dan tidak sekedar wacana saja agar validitas berita terjamin.

Informasi terkait bantuan sosial covid-19 ini berasal dari dinas yang menyelenggarakan bantuan kemudian jurnalis masing-masing dinas mengirimkan redaksi berita kepada Diskominfotiksan lalu setelah melewati ruang publik dan dapur redaksi barulah informasi dapat diterbitkan di website resmi pemerintah kota.

\section{Akuntabilitas}

Akuntabilitas adalah pengawasan yang dilakukan secara eksternal dalam penyelenggaraan pelayanan publik kepada masyarakat. Dalam hal ini diperlukan Standar Operasional Prosedur (SOP). Standar operasional prosedur ini dijadikan sebagai acuan dalam melaksanakan pelayanan dan sebagai pedoman penilaian kualitas pelayanan, dikatakan juga sebagai komitmen dari penyelenggaraan pelayanan kepada masyarakat.

Diskominfotiksan telah memiliki standar pelayanan yang jelas. Hal ini dapat dilihat di dalam ruangan Pejabat Pengelola Informasi Dokumentasi (PPID) terdapat standee baliho informasi mengenai prosedur pelayanan, mekanisme pengaduan, dan selebaran yang berisi informasi tentang persyaratan yang wajib dimiliki bagi setiap jenis pengurusan informasi tertentu.

\section{Faktor Pendukung Kinerja Diskominfotiksan dalam Menyampaikan Informasi Terkait Bantuan Sosial Covid-19}

Berdasarkan temuan penelitian terdapat tiga faktor yang mendukung kinerja organisasi, yaitu:

\section{Kemampuan}

Kemampuan merupakan kapabilitas dari tenaga kerja atau sumber daya manusia untuk menyelesaikan suatu pekerjaan. Kemampuan sumber daya manusia berhubungan dengan latar belakangnya seperti riwayat pendidikannya serta keahlian lainnya. Berdasarkan latar belakang pendidikannya, sumber daya manusia di Diskominfotiksan mempunyai latar belakang yang sesuai dengan kebutuhan organisasi. Hal ini menandakan bahwa latar belakang pendidikan pegawai dinyatakan sudah mampu memenuhi kebutuhan organisasi sebagai penyelenggara segala kegiatan yang ada di dinas tersebut.

Dalam menyebarkan informasi kepada masyarakat sumber daya manusia di Diskominfotiksan terutama pada Bidang Pengelolaan dan Layanan Informasi dan Komunikasi Publik sudah mampu dan terampil dalam mengelola sosial media dan kanal-kanal resmi pemerintah Kota Pekanbaru.

\section{Motivasi}

Motivasi merupakan suatu hal yang berkaitan dengan keinginan untuk melaksanakan pekerjaan. Dalam suatu organisasi, motivasi merupakan hal yang sangat diperlukan dalam hal mempengaruhi kinerja dari pegawai. Diskominfotiksan memberikan motivasi kerja kepada pegawai dengan cara menargetkan pencapaian. Hal ini dilakukan agar dinas dapat mempertahankan dan meningkatkan capaian yang telah didapatkan sebelumnya. Dalam hal ini, motivasi dianggap menjadi sebuah kebutuhan dalam menjalankan 
tugas organisasi. Tercapainya tujuan karena terdapat dorongan untuk mencapainya. Dorongan inilah menjadi hal yang amat penting bagi Diskominfotiksan dalam melaksanakan tanggung jawabnya sesuai dengan tugas pokok yang diberikan dan fungsi kerja masing-masing.

\section{Lingkungan Kerja}

Lingkungan kerja merupakan sumber daya dan keadaan yang diperlukan untuk melaksanakan suatu tugas. Pada indikator ini, dalam melaksanakan tugas dalam menginformasikan kegiatan pemerintah kota, Diskominfotiksan selalu berupaya. Dengan adanya dukungan dari pemerintah, yaitu menunjang terciptanya kinerja yang baik dari Diskominfotiksan melalui dukungan secara materi serta sarana dan prasarana. Selain dukungan dari pemerintah, lingkungan masyarakat juga menjadi faktor yang mempengaruhi kinerja Dinas Komunikasi, Informatika, Statistik, dan Persandian Kota Pekanbaru dalam menyampaikan informasi kepada masyarakat. Dinas Komunikasi, Informatika, Statistik, dan Persandian Kota Pekanbaru memiliki program Kelompok Informasi Masyarakat (KIM), program ini berhubungan langsung dengan masyarakat. Menurut pernyataan Kepala Seksi Kemitraan Informasi masyarakat, lingkungan kerja pada saat melaksanakan kegiatan sudah cukup baik.

\section{PENUTUP}

Kinerja Diskominfotisan dalam menyampaikan informasi terkait bantuan sosial covid-19 dapat disimpulkan sudah baik. Dalam menjalankan tugasnya sebagai organisasi pemerintah kota yang menyampaikan segala informasi atas kegiatan-kegiatan pemerintah dikatakan sudah bagus. Dapat disimpulkan juga bahwa Diskominfo berperan dalam meneruskan informasi terkait bantuan sosial covid-19 dari dinas yang memberikan bantuan kepada masyarakat melalui website resmi pemerintah kota. Maka dari itu, informasi-informasi yang kurang jelas bukan berasal dari Dinas Diskominfotiksan melainkan dari dinas terkait yang memberikan bantuan sosial covid-19 tersebut. Sementara itu, faktor-faktor yang mendukung kinerja Diskominfotiksan yaitu kemampuan, motivasi pegawai serta lingkungan kerja.

\section{DAFTAR PUSTAKA}

Ahdiyana, M. (2009). Memperkuat Manajemen Strategis Dengan Pengukuran Kinerja Dalam Organisasi Sektor Publik. Jurnal Ekonomi UNY.

Anggrahini, M. D dan Christina, R. (2008). Peran Humas Pemerintah Kabupaten Sragen dalam Pengelolaan Isi Informasi Website Pemda Sebagai Media Communications Relations dengan Masyarakat. Jurnal Ilmu Komunikasi, 6(2).

Arfan, S., Mayarni, M., \& Nasution, M. S. (2021). Responsivity of Public Services in Indonesia during the Covid-19 Pandemic. Budapest International Research and Critics Institute-Journal (BIRCI-Journal), 4(1), 552-562.

Barany, Lestary J. (2020). Bantuan Sosial Ekonomi di Tengah Pandemi COVID19. Sudahkah Menjaring Sesuai Sasaran? Retrieved from https://www.csis.or.id/download/243post-2020-04-15-

CSIS_Commentaries_ECON_002_ID_ DamuriEtAl.pdf

Dwiyanto, Agus. (2014. Mewujudkan Good Governance Melalui Pelayanan Publik. Yogyakarta: UGM Press.

Idris, I. K. (2015). Peran Humas Pemerintah di Era Keterbukaan Iniformasi (Analisis Isi Permenpan-RB No. 6 Tahun 2014 tentang Jabatan Fungsional Pranata Humas dan Angka Kreditnya. Jurnal Universitas Paramadina, 11(3), 11461163.

Lusiana, H. (2018). "Analisis Kinerja Karyawan Terhadap Produktifitas Kerja”. At-Tadbir: jurnal ilmiah manajemen, 2(1).

Muharanis, Rheiga. (2013). “Analisis Kinerja Aparatur dalam Pelayanan Masyarakat (Studi Kasus pada Dinas Sosial dan Tenaga Kerja Kota Tanjungpinang)". Masters thesis, Universitas Terbuka. Retrieved from http://repository.ut.ac.id/id/eprint/971. 
Nugroho, A. (2018). Analisis Produktivitas kerja karyawan outsourcing pada PT Siantar Putra Mandiri. Jurnal Analisis Produktifitas. Retrieved from http://repositorio. unan. edu. ni/2986/1/5624. pdf.

Peraturan Walikota Nomor 13 Tahun 2018 Tentang Kedudukan, Susunan Organisasi, Tugas dan Fungsi Serta Tata Kerja Dinas Komunikasi, Informatika, Statistik, dan Persandian Kota Pekanbaru.

Siahaan, S. (2019). "Peran Dinas Komunikasi Dan Informatika Pemerintah Kabupaten Tapanuli Utara Dalam Menyampaikan Informasi Pembangunan Pembangkit Listrik Tenaga Panas Bumi (Pltpb) Sarulla Kepada Masyarakat (Perspektif Komunikasi Islam)". (Doctoral dissertation, Universitas Islam Negeri Sumatera Utara).

Yohana Nova. (2014). "Pemanfaatan Website Pemerintah Kota Pekanbaru dalam Mewujudkan Good Governance". Jurnal Online Mahasiswa Universitas Riau. 